\title{
COMPARTIMENTAÇÃO MORFOPEDOLÓGICA DAS BACIAS HIDROGRÁFICAS DOS RIOS FERREIRA E ITAPIRAPUÃ E O PROCESSO DE FRAGMENTAÇÃO DAS COBERTURAS E USOS DE TERRAS
}

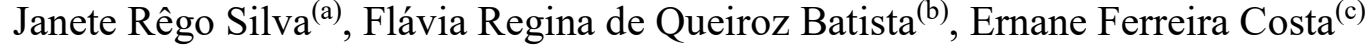 \\ (a) Campus Universitário de Niquelândia, Universidade Estadual de Goiás, janetegt25@gmail.com \\ (b) Programa de pós-gradução em Ciências Ambientais, Universidade Federal de Goias, frqbatista@gmail.com \\ (c) Instituto de Estudos Sociambientais, Universidade Federal de Goiás, ernane2010ferreira@ gmail.com
}

\section{Eixo: GEOTECNOLOGIAS E MODELAGEM ESPACIAL EM GEOGRAFIA FÍSICA}

\begin{abstract}
Resumo
As bacias hidrográficas dos rios Ferreira e Itapirapuã, no estado de Goiás passaram por um processo histórico de intensa conversão da cobertura vegetal nativa e ocupação das terras, e sofreram expressivos impactos ambientais. Este trabalho tem por objetivo analisar a relação entre os compartimentos morfopedológicos e os processos de fragamentação da cobertura e uso das terras relacionadas a este, em escala de detalhe. A definição dos compartimentos foi realizada com base nos dados do SRTM, utilizou-se imagens LANDSAT e RapidEye. Para tanto, foram produzidos mapas de cobertura e uso das terras, da compartimentação morfopedológica da área e calculadas as métricas de fragmentação da paisagem. Como resultado constatou-se que, as áreas dos topos dos morros e as próximas aos cursos d'água ainda possuem uma cobertura remanecesnte bem conservada, por manterem uma maior proporção de fitofisionomias florestal e savânica, enquanto as áreas mais aplainadas estão convertidas em pastagem.
\end{abstract}

Palavras chave: Compartimentação Morfopedológica. Bacia Hidrográfica. Fragmentação da pasiagem.

\section{Introdução}

Compartimentos morfopedológicos são unidades ambientais distinguíveis na paisagem na forma de áreas homogêneas intrínsecas e integradas do seu meio físico, manifestos como conjuntos físionômicos individualizados, que resultam em características fisiográficas e funcionais distintas dos seus vizinhos (NUNES, 2015).

Por vezes as ações antrópicas de mudança da cobertura e uso das terras alteram significativamente a paisagem, no que diz respeito à vegetação nativa, solos e mesmo o relevo, quando o manejo das terras não está de acordo com as condições naturais dos ambientes. Por outro lado, as demandas atuais por terras tem aumentado o desmatamento e assim alterado estas condições. No bioma Cerrado a conversão das áreas de vegetação natural para pastagem ocupa mais de $29 \%$ do bioma (BRASIL, 2015). 
No que diz respeito às mudanças de cobertura e uso no Cerrado, a região da Bacia Hidrográfica do Rio Vermelho, em Goiás, foi formada por um processo de ocupação relacionada num primeiro momento ao ciclo do ouro, mas no século vinte, por um processo de intensiva conversão da vegetação nativa para pastagem, com grandes fazendas de gado de corte e leiteiro (BARREIRA, 1997). As primeiras áreas ocupadas correspondiam às regiões de relevos mais aplainados e solos da classe dos latossolos, para então ocuparem áreas com relevos mais movimentados e solos menos favoráveis para conversão em pastagem (ESTEVAM, 1998).

As bacias hidrográficas dos rios Ferreira e Itapirapuã, situados na bacia hidrográfica do Rio Vermelho, no estado de Goiás, passaram por um processo histórico de intensa ocupação e alteração da cobertura uso das terras e expressivos impactos ambientais (VIEIRA, 2013). As áreas da bacia do rio Vermelho, especificamente as referidas sub-bacias dos rios Ferreira e Itapirapuã são regiões de atividade agropecuária e região de assentamentos de terras do Instituto Nacional de Colonização e Reforma Agrária (INCRA).

Com a caracterização morfopedológica pretende-se compreender melhor as possibilidades de uso das terras desta região e sugerir alternativas diante de suas potencialidades e limitações. O conhecimento das características pedológicas e geomorfológicas fornece subsídios para um melhor planejamento do uso da terra, visando o melhor aproveitamento das terras de forma sustentável.

Os processos de desmatamento que causam a redução dos ambientes naturais e por conseguinte aumenta a fragmentação ocorrem em escalas temporais distintas, em curto prazo reduzem o habitat, já em longo prazo induzem a insularização, assim reconhece-se que alguns biomas possuem apenas áreas de conservação como remanescente da vegetação natural (JESUS e MIURA, 2009). A fragmentação da vegetação do Cerrado pode causar diversas alterações, aumento do efeito de borda, invasão de espécies exóticas, modificações na composição especifica e na distribuição dos indivíduos na área (TURNER e COLLET, 1996).

O presente trabalho objetiva analisar a relação entre os compartimentos morfopedológicos, em escala de detalhe, e as alterações da cobertura e uso das terras relacionadas aos processos de fragmentação da paisagem, de modo a identificar os fatores que condicionaram estes processos.

\section{Materiais e Métodos}

A área deste estudo corresponde partes das bacias hidrográficas do Rio Ferreira e do Rio Itapirapuã, duas sub-bacias pertencentes à bacia hidrográfica do Rio Vermelho (BHRV). Esta bacia é considerada a principal área de afluentes à margem direita do Rio Araguaia, e se localiza na região oeste do estado de 
Goiás (Figura 1). Tais sub-bacias abrangem os municípios de Goiás, Matrinchã, Faina e Itapirapuã, na porção nordeste da BHRV.

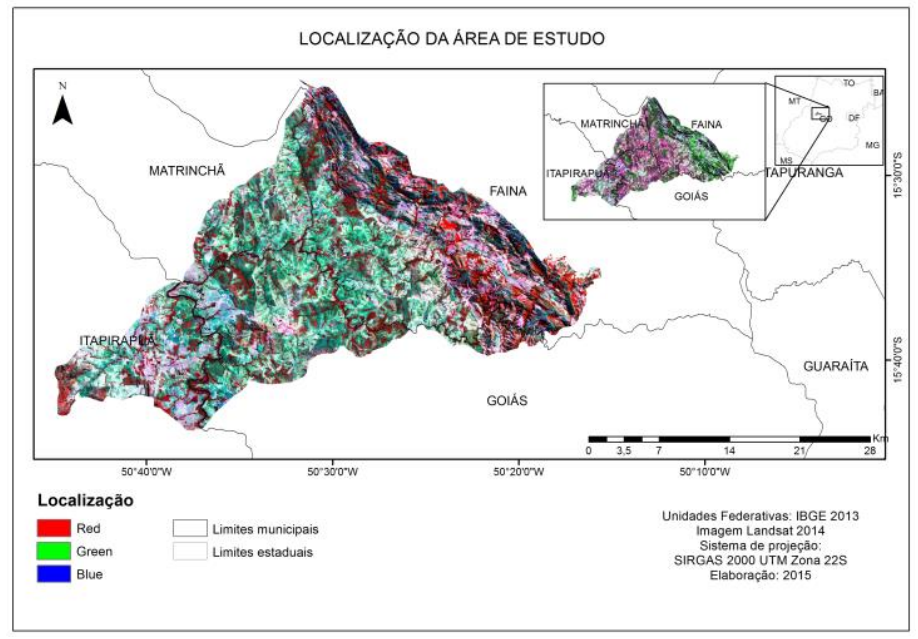

Figura 1: Carta imagem com a localização das bacias hidrográficas dos rios Ferreira e Itapirapuã, com composição colorida, vermelho (Red), verde (Green) e azul (Blue).

A vegetação nattiva da área de estudo é predominantemente savânica com zonas de tensão ecológica com florestas, em estado bastante fragmentado e em sua maior parte secundária, e composição florística alterada (SCARAMUZZA, 2008).

A geologia da área apresenta uma cobertura dendrítico-laterítica de idades Terciárias/Quaternárias, composta por sedimentos arenosos da formação Araguaia (Quaternário) e depósitos arenosos inconsolidados de planície aluvial (Holoceno) (VALENTE, 2007). Nas bacias as altitudes variam entre 300 e 850 metros, relacionadas à Serra de Santa Rita, associada ao greenstone belt de Santa Rita, com litotipos dobrados e falhados formados por metassedimentos e rochas metavulcânicas, xistos verdes e filitos (Figura 2) (VIEIRA, 2013).

Em relação as caracteristicas de relevo há a ocorrencia de áreas de sedimentos arenosos da depressão do rio Araguaia, responsáveis por formas mais concavizadas. A rede hidrológica destas bacias segue o contato estrutural definido por falhas entre os granitos-gnaisses do comlexo Uvá e os metassedimentos da Serra de Santa Rita, o que favorece a ocorrência de um padrão de drenagem dentritíco (Figura 2) (VIEIRA, 2013).

O Rio Vermelho é o principal canal fluvial da rede hidrológica e por isso empresta o nome à bacia, percorrendo 409,4 km desde a nascente, na cota de 900 metros, até a foz com o rio Araguaia, na cota de 220 metros, com direção preferencial ESE-WNW. Seus principais afluentes são o rio Água Limpa, pela esquerda, e o rio Ferreira, pela margem direita, que por sua vez forma a bacia de estudo deste trabalho, 


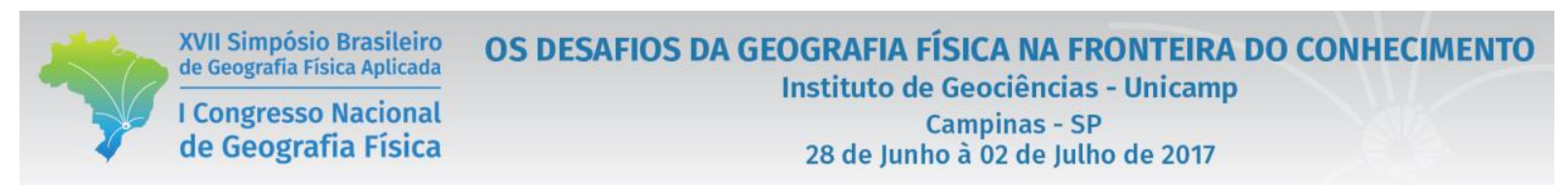

assim demonstrando sua importância em relação à região hidrográfica. Há um forte controle tectônico da bacia do rio Vermelho, o que colabora para a formação de canais com fortes rupturas de declive, e pequenas quedas d'água ao longo do curso (VIEIRA, 2013).

Os solos na região da bacia Hidrográfica do Rio Ferreira e do Rio Itapirapuã são predominantemente Cambissolos e Latossolos Vermelho-Amarelos, com Neossolos Litólicos nas áreas mais acidentadas (MACHADO e LIMA, 2011). Na figura 2 tem-se a síntese das caracteristicas do meio-físico, apresentando os mapas de solo, geologia, drengaem e relevo por cada compartimento delimitado.

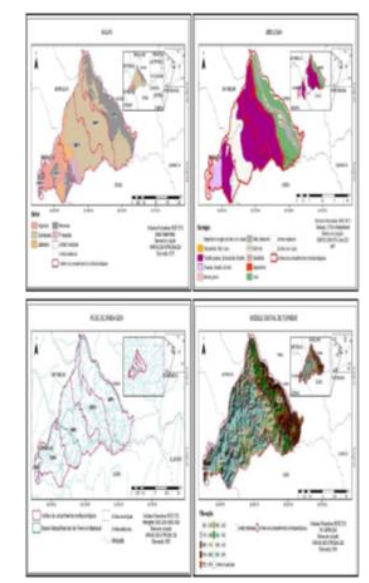

Figura 2: Mapas do meio físico das bacias dos rios Ferreira e Itapirapuã.

O modelo digital de elevação apresenta duas susperficies distintas no que diz respeito a altitude, e ao relevo, nota-se que na seção nordeste noroeste do mapa há a serra de Santa Rita, uma área mais elevada com altitude de $800 \mathrm{~m}$, já na seção do mapa de norte-sul é possivel verificar uma área com menores cotas de altitude de $300 \mathrm{~m}$, indicando um desnivel topográfico acentuado em uma área reduzida.

Para entender as diversas paisagens que recobriam a área de estudo, foi realizada a delimitação dos compartimentos morfopedológicos associados à estas paisagens, que permitiram verificar de que forma os mesmos se relacionam com as diferentes superfícies geomórficas e interagem com áreas antropizadas e as áreas preservadas (HERMUCHE et al., 2009). O limite conferido para delimitação dos compartimentos foi diferente dos limites que envolvem os divisores das duas bacias, uma vez que há uma área na bacia do Rio Ferreira, na qual há uma divisão das formas de relevo e drenagem diferente da porção mapeada.

A definição das áreas que correspondem a cada compartimento foi gerada utilizando os dados do Shuttle Radar Topographic Mission (SRTM) de 30 metros, do qual foi possível extrair os dados de declividade, altitude, curvatura das vertentes. 
O mapa de declividade utilizou escala em porcentagem, de acordo com as classes propostas pela EMBRAPA (0-3, 3-8, 8-20 e 20-40\%), as quais foram ajustadas para a área de estudo (EMBRAPA, 1999). O mapa de altitude (hipsométrico) foi gerado a partir da imagem do SRTM e ajustado para o Triangulated Irregular Network (TIN). O mapa de curvatura das vertentes foi obtido por meio da interpolação dos pixel da imagem com base nos valores de altitude. Utilzou-se ainda mapas de geologia e solos do portal de dados do Sistema Estadual de Geoinformação (SIEG).

A elaboração do mapa de cobertura e uso da terra, foi feito à partir da interpretação de imagens LANDSAT 8, sensor OLI Órbita/Ponto 223/71, dos anos de 1988, 1999 e 2014, com resolução espacial de 30m e sensor RapidEye com resolução de 5 metros, sendo esta do ano de 2013, todas convertidas para reflectância.

A classificação dos segmentos foi realizada, a partir da imagem segmentada, e por meio de inspeção visual, com apoio de imagens RapidEye, utilizando as bandas azul, vermelho, verde, infravermelho próximo e "red-edge", esta última voltada especialmente para a detecção de mudanças na vegetação.

Com base em conhecimento prévio da área foram definidas cinco classes de uso: área florestal, área savânica, pastagem, processo de desmatamento (áreas possíveis de visualizar com imagens Rapideye) e corpo hídrico. Para uma melhor caracterização da cobertura e uso da terra próximo aos corpos d'água foi gerado um "buffer" de 200m em torno destes, e calculadas as proporções de áreas para cada classe de uso. A medida de $200 \mathrm{~m}$ foi escolhida por questões de escala e diferenças entre as bases de dados vetoriais e imagens, com diferenças de forma e deslocamento dos corpos d'água.

Com base nos dados de cobertura e uso das terras foi possível gerar métricas da paisagem das quais se pôde inferir sobre a evolução da paisagem. As análises de fragmentação foram realizadas com o programa Fragstats 4.2 para a obtenção das métricas nos diferentes compartimentos, nas três datas selecionadas: 1988, 1999 e 2014. Entre as métricas geradas pelo programa foram selecionadas para análise as seguintes: Densidade de fragmentos (PD): Quantidade de fragmentos em que está dividida determinada classe de uso em relação à sua área total. Valor dado em unidade para cada 100 hectares. Conectividade (CONNECT): Representa a quantidade de junções entre pares de fragmentos de uma determinada classe de uso, sendo as conexões determinadas segundo o limite de distância entre fragmentos dado pelo usuário, esta é dada em porcentagem do máximo de junções possíveis.

Foram realizados testes de Levene para avaliar a homogeneidade de variâncias entre amostras e investigada a normalidade dos dados, para em seguida executar análises estatísticas do tipo ANOVA de medidas repetidas e teste Tuckey. Os testes compararam os dados de conectividade e densidade de fragmentos de cada classe de uso nas três datas estudadas: 1988, 1999, 2014. 


\section{Resultados e Discussões}

A área total dos compartimentos morfopedológicos corresponde a $822 \mathrm{~km}^{2}$ (tabela 1). O compartimento morfopedológico 1 possui a maior área dos cinco compartimentos definidos (tabela 1), este corresponde a uma sequência de xistos, dolomitos e filitos do grupo Greenstone Belt, rochas metamórficas, as quais dão sustentação à serra de Santa Rita, uma sequência de rochas que forma um relevo forte movimentado, com solos da classe dos Neossolos Litólicos com textura de cascalho e alguns pontos de afloramento rochosos.

O compartimento morfopedológio 2 com uma área de $180 \mathrm{Km}^{2}$ (tabela 1), corresponde ao grupo Uvá, com rochas da classe dos granitos, granodiorito e tonalito gnaisses, metamórficas e ígneas. O relevo deste compartimento se apresenta aplainado em relação ao primeiro, mas, ainda ondulado, sendo que o padrão da rede de drenagem é dendrítico, tendo algumas nascentes nesta área, predominando a classe dos Cambissolos, cascalhentos e com textura média.

O terceiro compartimento, situa-se na transição de rochas do complexo Uvá com as formação Araguaia. As rochas destas duas unidades são formadas por granitos, granodioritos e gnaisses e da segunda formação estão rochas de depósitos de silte, argila e areia. Neste compartimento o relevo é mais plano com vertentes que se apresentam mais convexizadas, formando rampas de forma ondulada. A classe de solo predominante neste compartimento é a dos Cambissolos Háplicos seguidos dos Latossolos Vermelho com textura média a argilosa, Plintossolos textura argilosa e uma pequena macha de Neossolo litólico com textura média.

O quarto compartimento delimitado possui um área de $135 \mathrm{Km}^{2}$ sendo formado por rochas do complexo arco magmático de Goiás e complexo granito-gnaisse, rochas do tipo tonalito gnaisse, granodiorito e granitos, originando Latossolo Vermelho com textura média e argilosa, Argissolo Vermelho com textura média e uma pequena mancha de Neossolo litólico com textura média. O relevo apresenta vertentes côncavas suavizadas e curtas.

O último compartimento corresponde a menor área de todos os compartimentos $15 \mathrm{Km}^{2}$, sendo este um pequeno morro no exutório da bacia do rio Itapirapuã, pertencente ao complexo magmático de Goiás, com rochas do tipo biotita granito, relevo de morro, com solo da classe dos Neossolos Litolícos de textura média. 


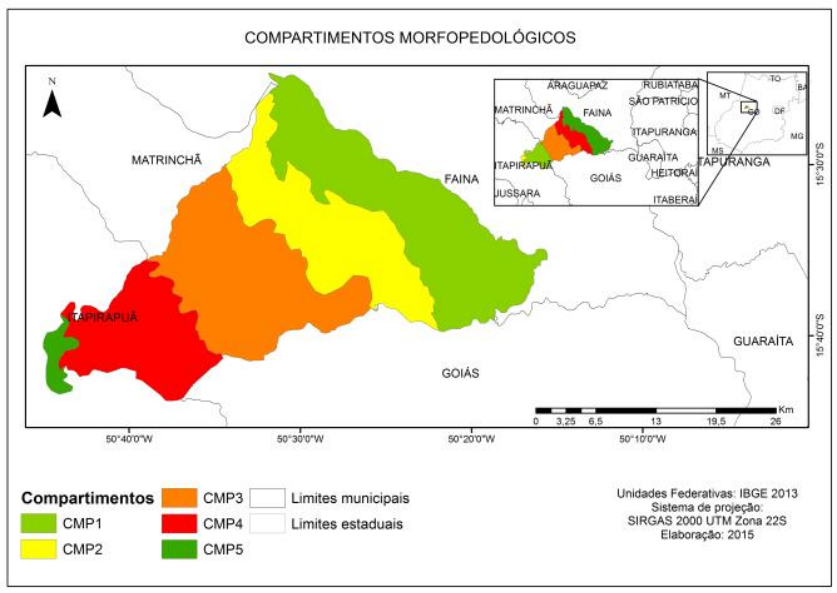

Figura 3: Compartimentos morfopedológicos das bacias dos rios Ferreira e Itapirapuã.

Tabela 1: Área de cada compartimento morfopedológico (CMP) das bacias dos rios Ferreira e Itapirapuã

\begin{tabular}{c|c|c}
\hline Compartimento Morfopedológico & Áreas em $\mathrm{Km}^{2}$ & $\%$ na bacia \\
\hline CMP1 & 258,30 & 31 \\
\hline CMP2 & 180,95 & 22 \\
\hline CMP3 & 231,42 & 28 \\
\hline CMP4 & 135,97 & 17 \\
\hline CMP5 & 15,64 & 2 \\
\hline
\end{tabular}

A cobertura e uso da terra na região (Figura 4) mostra que a pecuária é a principal e quase exclusiva responsável pela conversão de uso da terra. A área mapeada se apresentou, em 2014, 27\% coberta por pastagens e 73\% por vegetação florestal e savânica (Figura 5), com uma diminuição de 6 pontos percentuais na quantidade de pastagens e aumento de 6 pontos percentuais (Figura 5) na vegetação florestal e savânica em regiões mais próximas a corpos d'água (Figura 4). Estas proporções de pastagem estão bem de acordo com a média de áreas convertidas para pastagem no bioma Cerrado, que é de $29 \%$ (BRASIL, 2015).

As bacias dos rios Ferreira e Itapirapuã são áreas em que o processo de ocupação mais intenso se deu por meados das décadas de 1960 e teve uma estabilização de conversão nas décadas de 1990 e 2000, portanto pode verificar que os resultados de 1988, 1999 e 2014 mostra declínio na área de vegetação savânica em detrimento do aumento nas áreas de pastagem e floresta (Figura 4). 


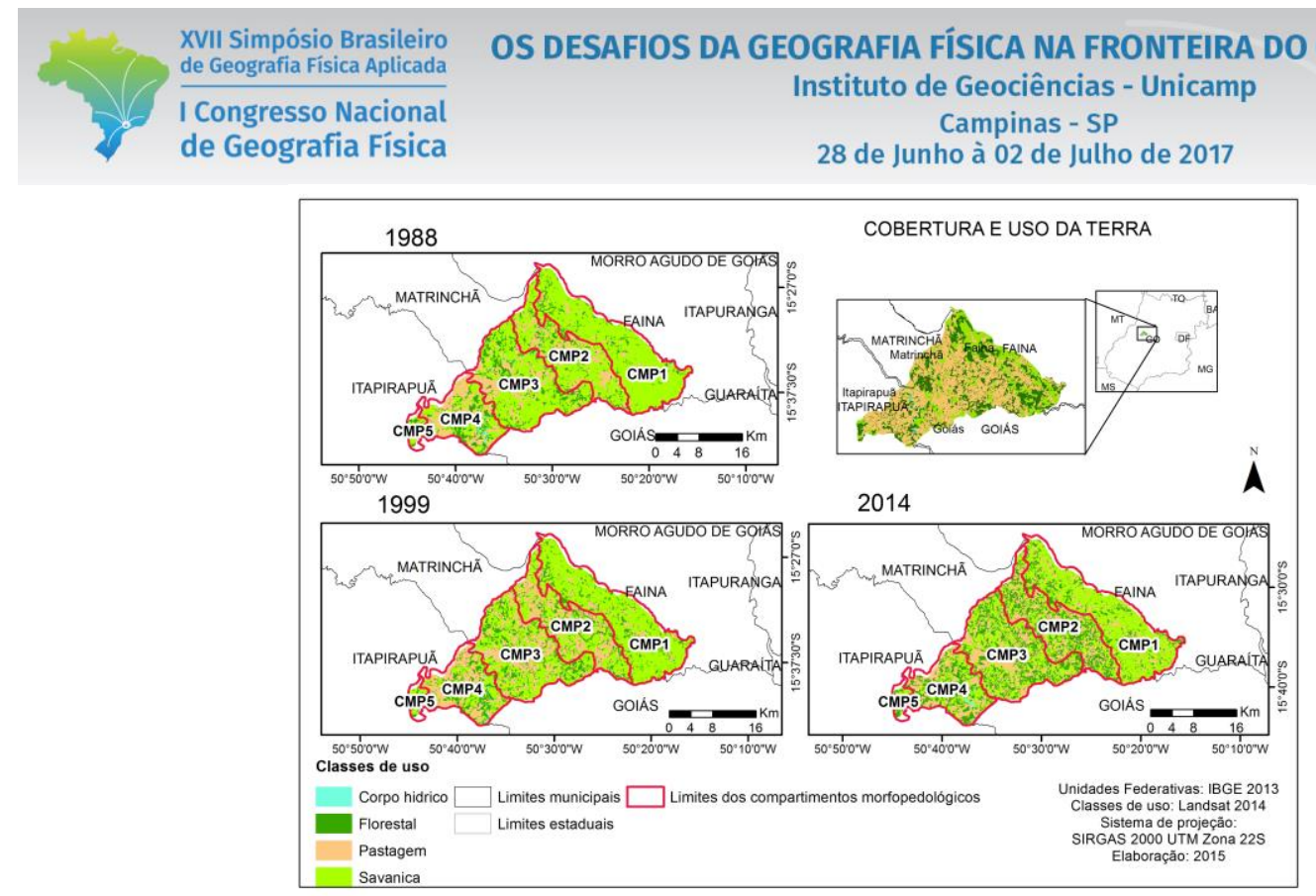

Figura 4: Cobertura e uso da terras das bacias dos rios Ferreira e Itapirapuã.

A comparação das proporções de classes de uso em cada compartimento revela que os compartimentos CMP1 e CMP5 apresentam menor quantidade de área convertida para pastagem, ainda que haja um aumento nesta classe de uso no período avaliado respectivamente 5,2\%, 8,35 e 15,2\%, os compartimentos CMP2 e CMP4 apresentaram as maiores proporções de conversão para pastagem. As maiores taxas de desmatamento situam-se no compartimento CPM3. Os compartimentos que apresentam menores proporções de área convertida são os que ainda possuem maior quantidade de vegetação florestal e savânica, e apresentam características físicas inapropriada para uso antrópico.

O compartimento 2 apresenta relevo predominantemente suave ondulado com Cambissolos em toda a sua extensão, adequado para o uso ao qual foi convertido. Já o compartimento 4, formado por vertentes côncavas, suavizadas e curtas, favorece uma maior deposição de sedimentos, com solos férteis, formado por Argissolo e Latossolo, ainda com Neossolo litólico, os solos mais férteis poderiam ser mais bem aproveitado para atividades agrícolas.

Figura 5: Porcentagem de área mapeada de cada uso das terras nas bacias dos rios Ferreira e Itapirapuã, 1988, 1999 e 2014.

Em geral nenhuma das classes de cobertura e uso das terras da área estudada sofreu alteração significativa dada a variância $F(9,34,223) \mathrm{p}>0,005$, o que pode ser percebido na figura 6 , as áreas de cobertura e uso não se alteram significativamente com os anos, é possível notar um aumento nas áreas da classe florestal, 


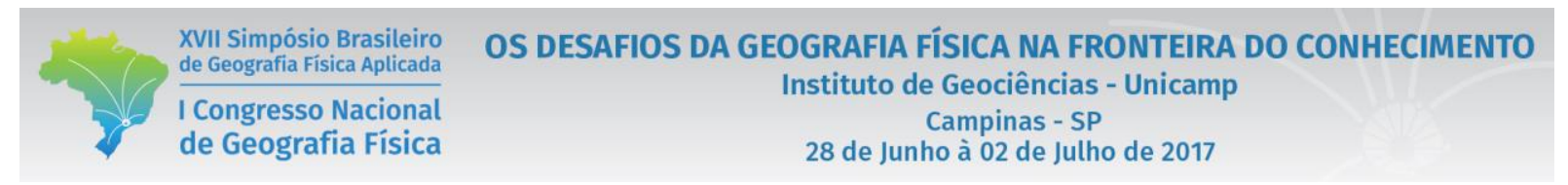

o qual pode ter sido favorecido pela recuperação de áreas de APP, sendo que estas podem ser utilizadas como áreas de reserva legal, de acordo com o novo código florestal.

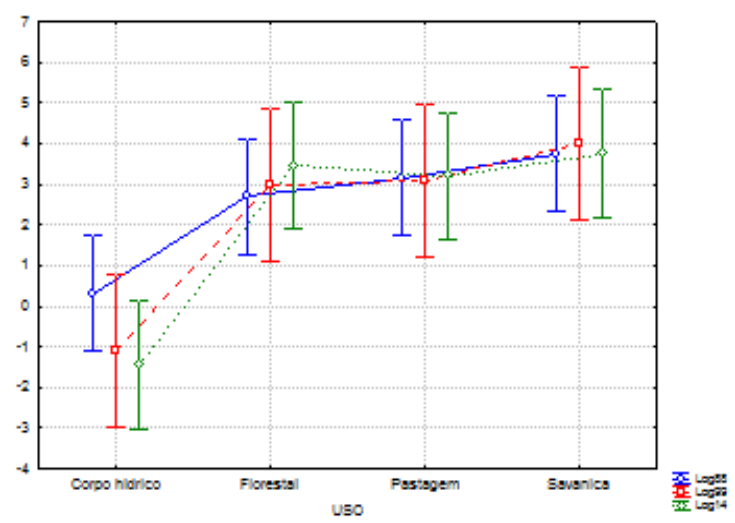

Figura 6: Área das Classes de cobertura e uso das terras nas bacias dos rios Itapirapuã e Ferreira.

O compartimento morfopedológico 3 é uma vertente convexa, mais suscetível à erosão do que áreas côncavas, já que este compartimento é formado em sua maior parte por Cambissolos, embora ocorram também Argissolos, Plintossolos e Neossolos litólicos. Possui também grandes áreas convertidas para pastagem, embora menor que nos compartimentos 2 e 4 . Os Plintossolos deveriam estar sendo conservados com vegetação nativa, uma vez que são mais frágeis em relação aos demais, no entanto, estão sendo quase totalmente utilizados como pastagem, assim como os Latossolos e os Neossolos.

As áreas formadas por Cambissolos deste compartimento são adequadas para uso como pastagem, desde que haja manejo adequado, e de fato grande parte delas está convertida para este uso, mas é aí que estão as maiores proporções de vegetação florestal e savânica. O compartimento 3 apresenta a maior proporção de áreas em processo de desmatamento (Tabela 2) possivelmente por ser o que ainda apresenta grandes proporções de áreas adequadas ao uso como pastagem ainda não convertidas.

Tabela 2: Valores de desmatamento, em percentual, de acordo com cada compartimento das bacias dos rios Ferreira e Itapirapuã.

\begin{tabular}{c|c|c|c|c|c} 
Classe de uso & CMP1 \% & CMP2 \% & CMP3 \% & CMP4 \% & CMP5 \% \\
\hline Em processo de desmatamento & 1,89 & 0,86 & 2,71 & 1,60 & 2,51 \\
\hline
\end{tabular}

Os compartimentos morfopedológicos 1 e 5 são os que apresentam menor proporção de áreas convertidas. Devido à sua declividade acentuada estes compartimentos são sensíveis à erosão, de forma que a preservação da vegetação nativa é de suma importância para a conservação. Além disso, seus solos são predominantemente Neossolos Litólicos, pouco profundos, sem horizonte B, não recomendados para 


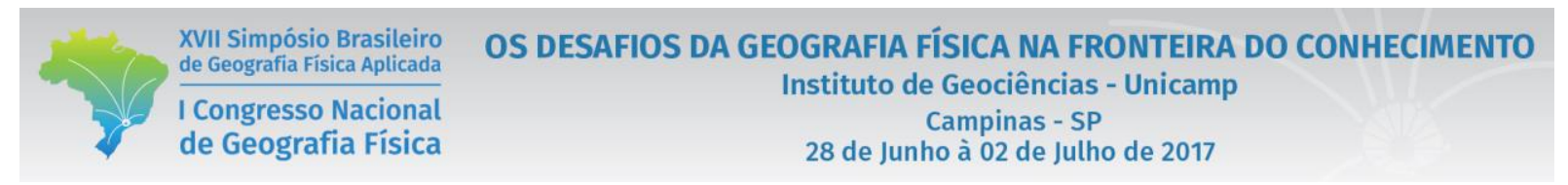

produção agrícola ou pecuária. No compartimento morfopedológico 5 há uma pequena proporção de Argissolos, que correspondem à área convertida para pastagens, e no compartimento morfopedológico 1, existe uma área com Cambissolos, também parcialmente convertida em pastagens, assim como uma pequena parte dos Neossolos Litólicos deste compartimento. Esta forma de ocupação dos compartimentos nos indica que o fator de contenção do desmatamento nestas áreas é a qualidade do solo e o relevo, e não a necessidade de conservação. Em todos os compartimentos foi observada redução na proporção de vegetação savânica entre 1988 e 2014 e aumento nas proporções de pastagem e vegetação florestal.

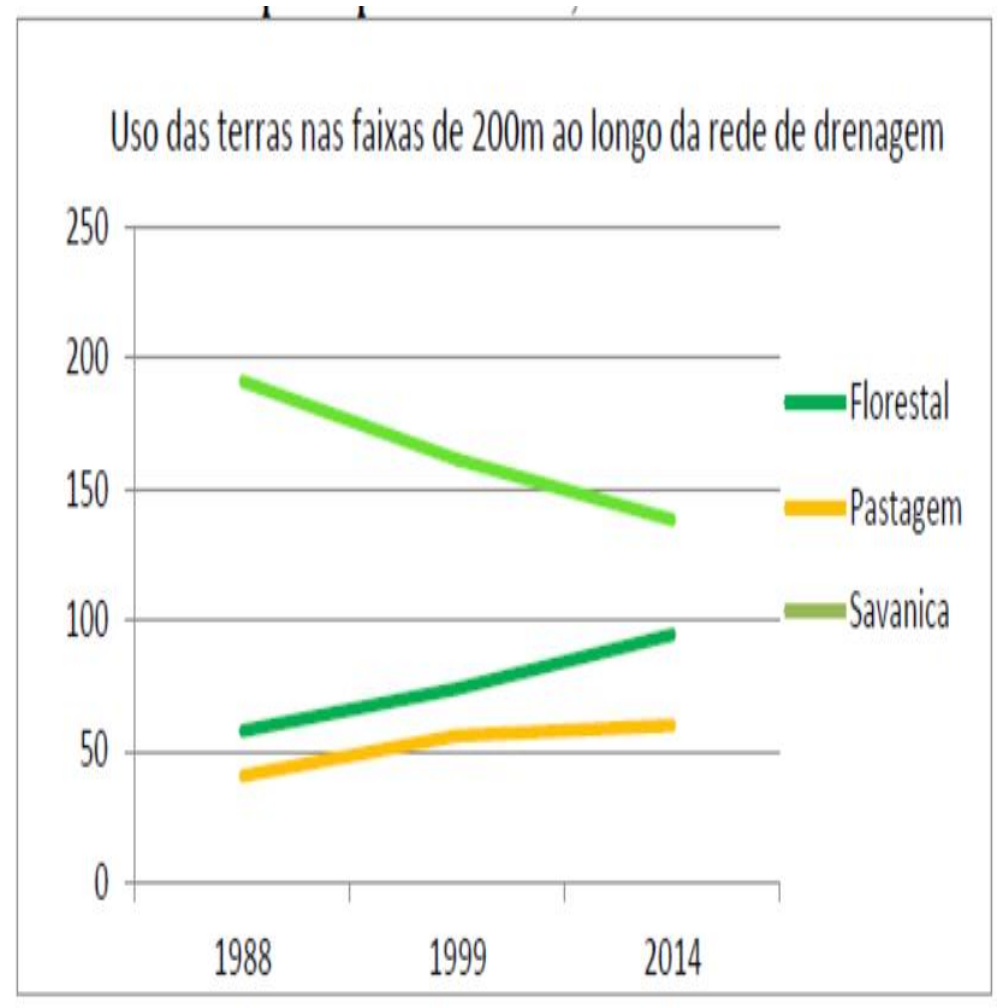

Figura 7: Classes de cobertura e uso das terras nas áreas de APP com buffer de 200m, para o período de 1988 , 1999 e 2014.

Nas áreas ao longo de corpos d'água, delimitadas em faixas de $200 \mathrm{~m}$, há um aumento de $12 \%$ na proporção de vegetação florestal entre 1988 e 2014 (Figura 7), o que representa o dobro do valor relativo de aumento de área florestal em toda a bacia. Esta recuperação se deu em detrimento da vegetação savânica, que diminuiu $21 \%$ em área relativa à extensão total da bacia no mesmo período. Simultaneamente houve aumento de $7 \%$ na área relativa dedicada a pastagens. Este resultado indica uma possível tendência à preservação das áreas de APP, sem abrir mão do aumento das áreas de pastagem e aumentando a pressão sobre áreas savânicas.

Para as classes de uso pastagem e vegetação florestal foi observado aumento de densidade de fragmentos e redução na conectividade entre 1988 e 2014 em todos os compartimentos (Figura 8). A classe de uso 


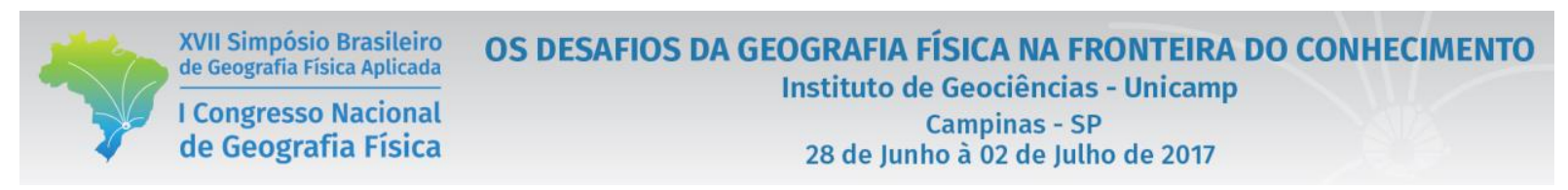

savânica apresentou comportamento mais heterogêneo entre os compartimentos ao longo do tempo, com aumento de densidade de fragmentos em todos os compartimentos e diminuição da conectividade nos compartimentos 1,3 e 4, e aumento de conectividade nos compartimentos 2 e 5 .
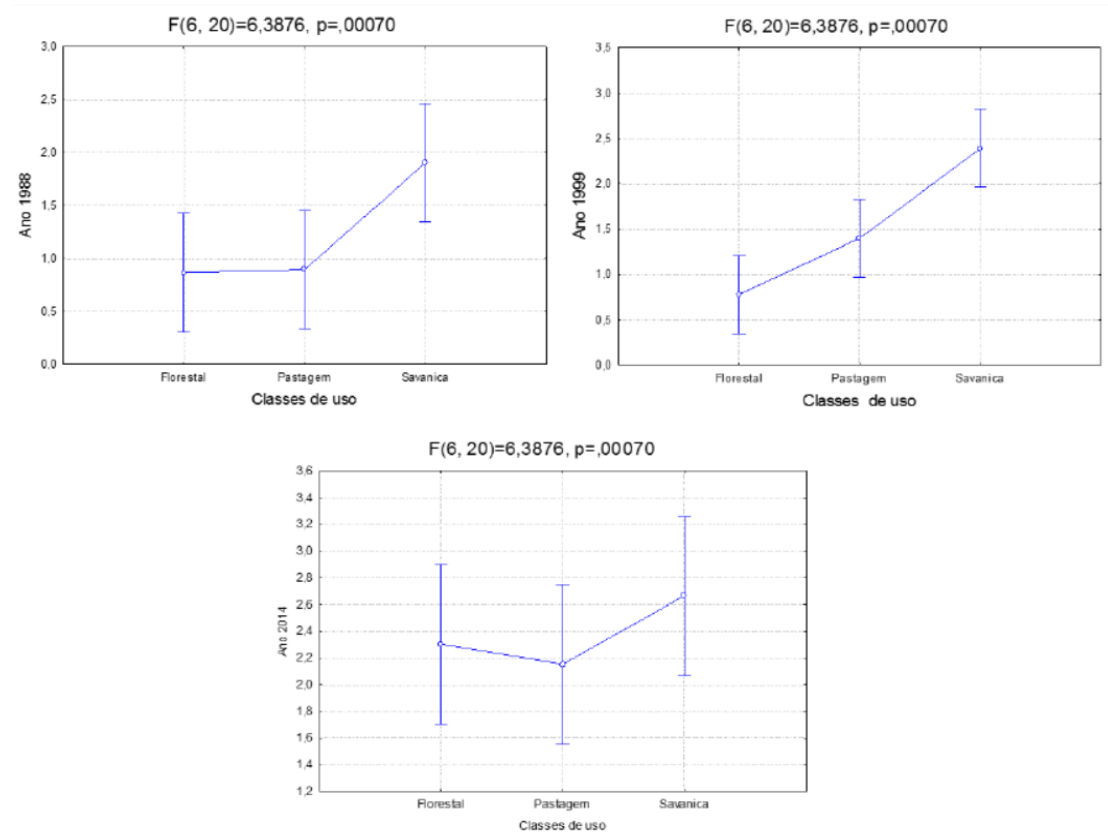

Figura 8: Densidade de fragmentos nas diferentes classes de uso no ano de 1988, 1999 e 2014.

Destaca-se que os compartimentos de 1 a 4 tem oscilações uma ordem de grandeza inferiores ao aumento ocorrido no compartimento 5. A perda de conectividade das áreas naturais indica um forte processo de perda da diversidade biológica e funcional das áreas de Cerrado presentes nos compartimentos 1, 3, e 4.

\section{Conclusões}

A delimitação de compartimentos morfopedológicos possibilitou a caracterização e interpretação das áreas de acordo com suas características fisiográficas e mesmo do uso antrópico. Foram delimitados cinco compartimentos morfopedológicos na escala de 1:100.000, tendo sido possível relacionar as características físicas do ambiente e as formas de mudança da cobertura e uso das terras, de tal forma que produzem áreas com tipologia de fragmentação variada os quais favorecem a perda diversidade biológica.

A metodologia de mapeamento dos compartimentos morfopedológicos pode ser replicada para outras áreas de interesse, para que produtores e gestores públicos possam utilizar de maneira mais adequada as áreas de acordo com seu potencial de capacidade de uso das terras. 
Identificou-se que a fragmentação dos compartimentos está diretamente associada as caracteristicas do meio físco, de tal forma que no CMP1 em que se tem um relevo mais dissecado foi possivel encontrar uma cobertura remanescente mais preservada em relação aos demais compartimentos.

Para melhor entendimento das relações entre uso das terras e morfopedologia convém elaborar um mapeamento em escala de 1:20.000, por exemplo, para que se possa indicar melhor quais áreas seriam mais adequadas ao uso para pecuária, agricultura, silvicultura e propor de que melhor forma poderiam ser conservados os remanescentes. Desta forma os pequenos agricultores, assentados ou não, poderiam utilizar melhor as áreas de suas propriedades.

\section{Referências Bibliográficas}

BARREIRA, C. C. M. A.; Região da Estrada do Boi: Usos e Abusos da Natureza. 1. ed. Goiânia: UFG, 1997. v. 1. 154p.

BRASIL, MINISTÉRIO DO MEIO AMBIENTE. Mapeamento do Uso e Cobertura do Cerrado: Projeto TerraClass Cerrado, 2013, MMA, sbf. Brasília: MMA, 2015. 67p.,

ESTEVAM, L. O tempo da transformação - estrutura e dinâmica da formação econômica de Goiás. Goiânia: ed. do autor, 1998.

EMBRAPA-EMPRESA BRASILEIRA DE PESQUISA AGROPECUÁRIA. Sistema Brasileiro de Classificação dos Solos. Brasília: DF, 1999.

JESUS, S. C., MIURA, A.K., Análise espacial de fragmentos de Cerrado como subsídio para a seleção de áreas prioritárias para a conservação. Anais do XIV Simpósio Brasileiro de Sensoriamento Remoto, Natal, Brasil, 25-30 abril, 2009, INPE, 3943-3950 p.;

HERMUCHE, P. M., GUIMARÃES, G., M., A., CASTRO, S. S., Análise dos Compartimentos Morfopedológicos como Subsídios ao Planejamento do Uso do Solo em Jataí- GO. GEOUSP - Espaço e Tempo, $\mathrm{n}^{\circ}$ 26, São Paulo, 2009, 113-131 p.,

MACHADO, L. E D; LIMA, C. V; Compartimentação geomorfológica da bacia hidrográfica do Rio Vermelho (GO) utilizando imagens ASTER. XV Simpósio Brasileiro de Sensoriamento Remoto - SBSR. 2011 Curitiba - PR. NUNES, E. D; Modelagem de processos hídricos lineares no município de Mineiros - GO: Compartimentação morfopedológica, parâmentros morfométricos e morfográficos do relevo e sistemas pedológicos associados. Tese de Doutorado. IESA-UFG. 2015. 242 p.

SCARAMUZZA, C. A. M. et al., Áreas prioritárias para a conservação da biodiversidade em Goiás. In. A encruzilhada socioambiental: Biodiversidade, economia e sustentabilidade no Cerrado. Org. Ferreira, L. G. Editora UFG. 2008.

BRASIL. Ministério do Meio Ambiente - MMA. Mapeamento do Uso e Cobertura do Cerrado: TerraClass Cerrado 2013. MMA, SBF. Brasília: MMA, 2015. 67 p.

TURNER, I.M.; CHOONG, M.F.; TAN, H.T.; LUCAS P.W. How tough are sclerophylls? Annals of Botany, 71, 1996, 343-345 p.;

VALENTE, C. R. Geotectonic, geologic evolution and regional geomorphology of the Araguaia river basin, Central Brazil. Tese de Doutorado. CIAMB-UFG. 2007. 204 p. 


\begin{tabular}{|c|c|}
\hline $\begin{array}{l}\text { XVII Simpósio Brasileiro } \\
\text { de Geografia Fisica Aplicada } \\
\end{array}$ & $\begin{array}{l}\text { OS DESAFIOS DA GEOGRAFIA FÍSICA NA FRONTEIRA DO CONHECIMENTO } \\
\text { Instituto de Geociências - Unicamp }\end{array}$ \\
\hline $\begin{array}{l}\text { I Congresso Nacional } \\
\text { de Geografia Física }\end{array}$ & $\begin{array}{l}\text { Campinas - SP } \\
28 \text { de Junho à } 02 \text { de Julho de } 2017\end{array}$ \\
\hline
\end{tabular}

VIEIRA, P. A. Dinâmica de ocupação, vulnerabilidade e cenários para a Bacia Hidrográfica do Rio Vermelho, Goiás. Tese de doutorado. CIAMB-UFG. 2013. 93p. 